\title{
The Antioxidant Effects of Ziziphus Jujuba on Neurodegeneration
}

\author{
Altuğ Küçükgül \\ Mustafa Kemal University, Veterinary Faculty, Department of Biochemistry, Hatay
}

Geliş Tarihi / Received: 18.10.2016, Kabul Tarihi / Accepted: 15.11.2016

\begin{abstract}
Oxidative stress has been known to play an important role in the pathogenesis of various neurodegenerative diseases. Dietary polyphenols and other natural antioxidants are the most popular compounds in clinical testing for the elimination of neurodegeneration. It has been demonstrated in recent studies that fruit of Zizyphus jujuba possesses several vital biological activities. This study intends to evaluate antioxidant activity of Zizyphus jujuba on human glioblastoma cells. Cell survival was quantified by colorimetric viability assay with dose response. Cells were pretreated with $100 \mu \mathrm{M}$ Ziziphus jujuba essential oil for $1 \mathrm{~h}$, then $100 \mu \mathrm{M} \mathrm{H}_{2} \mathrm{O}_{2}$ was added to the cells for 12 hours. After that, the cell medium were taken after treatment period and replaced with fresh medium. Total oxidant capacity (TOS) and total antioxidant capacity (TAS) levels were estimated using specific colorimetric methods. Oxidative stress index (OSI) was calculated from the ratio of TOS and TAS values. Many researches have been reported that the essential oil from seeds helps to prevent the oxidative stress induced neuronal diseases. The antioxidant potential of Ziziphus jujuba may be attributed to the presence of flavonoids and the other constituents present therein. Our data suggested that Ziziphus jujuba is effective in preventing $\mathrm{H}_{2} \mathrm{O}_{2}$-induced oxidative stress.
\end{abstract}

Key words: Oxidative stress, Neurodegeneration, Ziziphus jujuba

\section{Nörodejenerasyonda Ziziphus Jujuba'in Antioksidan Etkileri}

Özet: Oksidatif stresin çeşitli nörodejeneratif hastalıkların patogenezinde önemli bir rol oynadığı bilinmektedir. Diyet polifenolleri ve diğer doğal antioksidanlar nörodejenerasyonun giderilmesi amacıyla yapılan klinik testlerde en popüler bileşiklerdir. Yapılan güncel çalışmalarda, bir çeşit yemiş olan Zizyphus jujuba'nın birçok önemli biyolojik aktivitelere sahip olduğu rapor edilmiştir. Bu çalışma, insan glioblastoma hücreleri üzerinde Zizyphus jujuba'nın antioksidan etkinliğinin araştırılması amaçlamaktadır. Hücre canlılığı, doza bağlı kolorimetrik viyabilite testleri ile belirlenmiştir. Hücreler, 1 saat $100 \mu \mathrm{M}$ Ziziphus jujuba'nın uçucu yağları ile ön-muamele edilip, daha sonra $100 \mu \mathrm{M} \mathrm{H}_{2} \mathrm{O}_{2} 12$ saat boyunca hücrelere ilave edildi. Uygulamalar sonunda hücre homojenatları uzaklaştırılarak taze besiyeri ile değiştirildi. Total oksidan kapasite (TOS) ve total antioksidan kapasite (TAS) düzeyleri spesifik kolorimetrik yöntemler kullanılarak tayin edilmiştir. Oksidatif stress indeksi (OSI) TOS ve TAS değerlerinin oranlamasıyla elde edilmiştir. Birçok araştırmada doğal bitkilerden elde edilen uçucu yağların oksidatif stress uyarımlı nöronal hastalıkları önlemeye yardımcı oldukları rapor edilmiştir. Ziziphus jujuba'nın antioksidan etkinliğinin içerisinde bulunan flavonoidler ve diğer bileşenlere bağlı olduğu düşünülmektedir. Elde edilen veriler göre, Ziziphus jujuba'nın $\mathrm{H}_{2} \mathrm{O}_{2}$ kaynaklı oksidatif stresi önlemede etkili olduğu öngörülmektedir.

Anahtar kelimeler: Oksidatif stres, Nörodejenerasyon, Ziziphus jujube

\section{Introduction}

Cellular and molecular signaling failure is the main reason for many human disorders and signal transduction defects and the proteins involved in these processes are the mayor elements for neurodegenerative disorders such as Alzheimer's disease (AD) and Parkinson's disease (PD) [3,23]. It is stated that many factors like environmental, genetic predisposition and abnormal metal metabolism plays a critical role in neurodegeneration [22]. Free radicals catalyzed by redox metals and oxidative stress are the most important reasons for the development of neurodegeneration [7].

Oxidative stress occurs as a result of the release of reactive oxygen species (ROS) [26]. Free radicals can be produced from endogenous sources, such as from mitochondria, peroxisomes, and inflammatory cell activation and exogenous sources, including environmental agents, pharmaceuticals, and industrial chemicals [19]. Brain is particularly sensitive to free radicals because of having antioxidant enzymes in low concentration and the consumption about $20 \%$ of the body's total oxygen [9]. Recent studies have 
indicated that ROS causes oxidative stress and programmed cell death in neuronal cells [27].

Herbs contain a wide variety of molecules including phenolic compounds (flavonoids, quinons, tannins etc.), nitrogen compounds (alkaloids, amines), vitamins and terpenoids. These compunds exerts strong free radical scavenging and antioxidant properties $[2,30]$. The nutritional Ziziphus jujuba Mill., (ZJ) is a herbal plant used in traditional medicine, belongs to the Rhamnaceae family and it is one of the most important Ziziphus species $[6,14]$. Recent phytochemical studies of jujuba fruits have shed some light on their biological effects, such as the anticancer, anti-inflammatory, antiobesity, immunostimulating, antioxidant, hepatoprotective, and gastrointestinal protective activities and inhibition of foam cell formation in macrophages [10].

Herbal medicines are generally low in cost, plentiful, and show very little toxicity or side effects in clinical practice. Therefore, our main objective in this study is to investigate antioxidant effects of essential oil of Ziziphus Jujuba fruit on human glioblastoma cells.

\section{Materials and Methods}

Human glioblastoma (U87MG) was obtained from American Type Culture Collection (Manassas, VA) and maintained in DMEM supplemented with $10 \%$ fetal bovine serum, $2 \mathrm{mM}$ glutamine, $100 \mathrm{U} / \mathrm{ml}$ penincillin and $100 \mu \mathrm{g} / \mathrm{ml}$ streptomycin, at $37^{\circ} \mathrm{C}$ with $5 \% \mathrm{CO}_{2}$. Briefly, cells were plated in 24-well plates $\left(0.4 \times 10^{5}\right.$ cells $)$ and pretreated with $100 \mu \mathrm{M}$ Ziziphus jujuba essential oil for $1 \mathrm{~h}$ then $100 \mu \mathrm{M}$ $\mathrm{H}_{2} \mathrm{O}_{2}$ was added to each well for $12 \mathrm{~h}$. After the incubation, the supernatant was replaced by fresh medium.

The cell survival was quantified by the colorimetric MTT (4,5-dimethylthiazol-2-yl)-2,5-diphenyltetrazolium bromide) assay [13]. Following incubation period, cell culture at $37^{\circ} \mathrm{C}, 1 \mathrm{ml} /$ well of MTT (5 mg/ml-Sigma) was added to the wells, followed by incubation for an additional $2 \mathrm{~h}$ for each experiment time. The viable cells produced a dark blue formazan product, whereas no such staining was formed in the dead cells. The resulting formazan product was solubilized in $1 \mathrm{ml} /$ well of acidic isopropanol, and absorbance read at 570nm with ELISA reader ( $\mu$ Quant-USA).

The novel total antioxidant status (TAS) and total oxidant status (TOS) assays have been shown to be stable, reliable and sensitive to determine antioxidant and oxidant capacity of the biologic samples, respectively [8]. Total antioxidant level of the sample was calculated according to ABTS (dark blue colored radical) reducing capacity of antioxidants at $660 \mathrm{~nm}$. Results were given as Trolox equivalent $(\mathrm{mmol} / \mathrm{lt})$ which is a vitamin E analog. Additionally, oxidants in the sample oxidize ferrous-ion chelator complex to ferric ion. Briefly, total oxidant level was measured by colorimetric methods according to absorbance change of formed colored complex at $530 \mathrm{~nm}$. Results were given as $\mathrm{H}_{2} \mathrm{O}_{2}$ equivalent $(\mu \mathrm{mol} / \mathrm{lt})$. OSI was calculated as the ratio of TOS and TAS values.

\section{Statistical analysis}

The one-way analysis of variance (ANOVA) and post hoc Duncan tests were performed on the data to examine the differences among groups using the SPSS statistical software package. The results are presented as average \pm SE. A value of $p<0.05$ was considered significant.

\section{Results}

We used $\mathrm{H}_{2} \mathrm{O}_{2}$ treatment in order to model oxidative stress in our cellular system. Effect of $\mathrm{H}_{2} \mathrm{O}_{2}$ on cell viability were performed by MTT analysis. Viability of U87 cells were decreased straightly in a concentration-dependent manner over the range of 5 to 250 $\mu \mathrm{M}$ following $12 \mathrm{~h} \mathrm{H}_{2} \mathrm{O}_{2}$ treatment. The data showed that $100 \mu \mathrm{M} \mathrm{H}_{2} \mathrm{O}_{2}(0.190 \pm 0.008)$ killed about $42 \%$ of cells at the end of the incubation according to the control group $(0.329 \pm 0.011)(\mathrm{p}<0.05)$ (Fig.1A). However, $10 \mu \mathrm{M}$ ZJ $(0.367 \pm 0.026)$ increased the number viable cells by $17 \%$ as compared to control group $(0.3142 \pm 0.010)$. For this reason $10 \mu \mathrm{M}$ ZJ was used as a cell protective concentration for further experiments. Treatments utilizing $50 \mu \mathrm{M}$ and higher concentrations of $\mathrm{ZJ}$ decreased cell viability (Fig 1B). Morever, $10 \mu \mathrm{M} Z \mathrm{ZJ}(0.240 \pm 0.017)$ pre-treatment for $1 \mathrm{~h}$ prevented $25 \%$ of cell death caused by $\mathrm{H}_{2} \mathrm{O}_{2}(0.193 \pm 0.044)$ (Fig $\left.1 \mathrm{C}\right)$. 

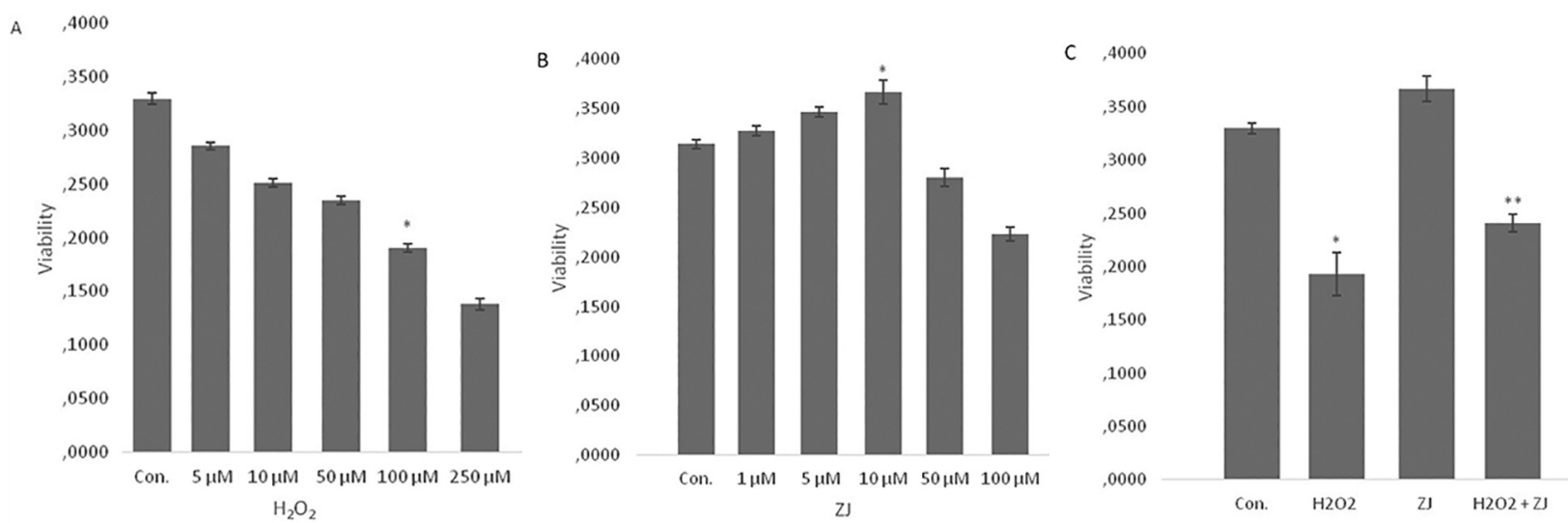

Figure 1. The effect of $Z$. Jujuba on cell viability in hydrogen peroxide induced oxidative stress. A. Dose dependent effect of $\mathrm{H}_{2} \mathrm{O}_{2}$ on U87 cell viability. B. Dose dependent effect of $\mathrm{ZJ}$ in viability. C. Dose dependent protective effect of $\mathrm{ZJ}$ on $\mathrm{H}_{2} \mathrm{O}_{2}$-induced cytotoxicity in cells. The data is represented as mean $\pm \mathrm{SD}$ of five independent experiments. ${ }^{*} \mathrm{p}<0.05$ versus control group. ${ }^{*} \mathrm{p}<0.05$ versus $\mathrm{H}_{2} \mathrm{O}_{2}$ group.

Hydrogen peroxide significantly enhanced total oxidant status (TOS) 3.88 times in human glioblastoma cell line U87 $(\mathrm{p}<0.05)$. The addition of Z. jujuba essential oil pretreatment decreased TOS by $18.67 \%$ in only jujuba group and in $13.22 \% \mathrm{ZJ}$ plus $\mathrm{H}_{2} \mathrm{O}_{2}$ group against control. The $\mathrm{ZJ}$ oil also has important effects (by 6.69\%) on $\mathrm{ZJ}$ plus $\mathrm{H}_{2} \mathrm{O}_{2}$ group when compared only. group (Table 1). Total antioxidant status levels significantly decreased by
$\mathrm{H}_{2} \mathrm{O}_{2}$ pretreatment but $\mathrm{ZJ}$ oil prevented the situation by $22.93 \%$ against control and by $68 \%$ against only $\mathrm{H}_{2} \mathrm{O}_{2}$ group. The antioxidant status of $\mathrm{ZJ}$ oil decreased $\mathrm{ZJ}$ plus $\mathrm{H}_{2} \mathrm{O}_{2}$ group. Hydrogen peroxide $(3.0 \pm 0.300)$ increased OSI as compared to control group $(0.141 \pm 0.014)$ (Table 1$)$. However, ZJ pretreatment $(0.142 \pm 0.015)$ significantly recovered this increase in OSI according to only $\mathrm{H}_{2} \mathrm{O}_{2}$ added group.

Table 1. Effects of CAPE treatment on total oxidant (TOS) and antioxidant (TAS) status in cells exposed to $\mathrm{H}_{2} \mathrm{O}_{2}$.

\begin{tabular}{|c|c|c|c|c|}
\hline & Control & $\mathrm{H}_{2} \mathrm{O}_{2}$ & ZJ & $\mathrm{H}_{2} \mathrm{O}_{2}+\mathrm{ZJ}$ \\
\hline TOS $\left(\mu \mathrm{mol} \mathrm{H} \mathrm{H}_{2} \mathrm{O}_{2}\right.$ equiv./lt $)$ & $2.570 \pm 0.171$ & $9.990 \pm 0.267^{*}$ & $2.090 \pm 0.114$ & $2.230 \pm 0.153^{* *}$ \\
\hline TAS (mmol Trolox equiv./lt) & $1.818 \pm 0.083$ & $0.330 \pm 0.056^{*}$ & $2.235 \pm 0.141$ & $1.563 \pm 0.182^{* *}$ \\
\hline $\mathrm{OSI}\left(\mu \mathrm{mol} \mathrm{H} \mathrm{O}_{2}\right.$ equiv./lt $) /(\mathrm{mmol}$ Trolox equiv./lt x 10) & $0.141 \pm 0.014$ & $3.0 \pm 0.300$ & $\begin{array}{c}0.093 \pm \\
0.010 \\
\end{array}$ & $0.142 \pm 0.015$ \\
\hline
\end{tabular}

The data are represented as mean $\pm \mathrm{SE} .{ }^{*} \mathrm{p}<0.05$ compared to control group; $* * \mathrm{p}<0.05$ compared to. $\mathrm{H}_{2} \mathrm{O}_{2}$-treated group. The cells were preincubated for $1 \mathrm{~h}$ with $10 \mu \mathrm{M}$ of $\mathrm{ZJ}$ then incubated for a further 12 $\mathrm{h}$ at $37^{\circ} \mathrm{C}$ in the presence of $100 \mu \mathrm{M} \mathrm{H}_{2} \mathrm{O}_{2}(\mathrm{n}=5)$. OSI: Oxidative stress index.

\section{Discussion}

Hydrogen peroxide can swiftly penetrate the cell membrane, reacting with intracellular metal ions such as iron or copper to form highly toxic hydroxyl radicals, which cause DNA alteration. Thus, even at lower concentration, $\mathrm{H}_{2} \mathrm{O}_{2}$ can cause heavy damage to the cultured cells. Some natural antioxidant products may be useful to protect neurons from oxidative injury. Clinically, malignant gliomas are among the least responsive of human tumors and for tumors of higher grades, complete remission and/ or long term survival is rare [24]. Kitamura et al., [18] demonstrated that in human A172 cells, hydrogen peroxide $\left(\mathrm{H}_{2} \mathrm{O}_{2}\right)$ caused cell death in a timeand concentration-dependent manner, accompanied by nucleosomal DNA fragmentation and chromatin 
condensation. Similar to our data obtained from this study, Tavakkoli et al., [29] reported that $75 \mu \mathrm{M}$ $\mathrm{H}_{2} \mathrm{O}_{2}$ treatment applied to the PC12 neuronal like cells for $1 \mathrm{~h}$ reduced cell viability significantly and triggered oxidative stress and apoptosis.

Herbal medicine in recent years gained a momentum in the treatment of many diseases, especially cancer and neurodegenerative diseases $[4,15]$. Phenolic compounds derived from jujuba in have been reported to show beneficial properties in neuronal tissue. Considering that treatment $\mathrm{H}_{2} \mathrm{O}_{2}$ with results in excess ROS, the present study suggests that oxidative stress may play a critical role in oxidative stress induced neuronal injury [17]. Our results indicated essential oil of jujuba prevented neuronal cell loss induced by $\mathrm{H}_{2} \mathrm{O}_{2}$. It has been reported in recent studies that although $\mathrm{ZJ}$ aqueous extract demonstrated proliferative effect on in vitro diabetic neuropathy model of on PC12 cells [15].

Medicinal plants have curative properties due to presence of various complex chemical substances of different composition which contain secondary metabolites such as alkaloids, flavonoids, terpenoids, saponin and phenolic compounds distributed in different parts of the plants. Studies demonstrated that, an indigenous plant possesses terrific medicinal properties, attributed by a diverse group of secondary metabolites. Also Z.Jujuba has photo-chemical, pharmacological, medicinal properties and biological activities [5,21]. Gao et al., [10] which studies five variations of $Z$. jujuba, demonstrated the antioxidative and free radical scavenging effect of the this plant. Taatil et al., [28] showed that Z. jujuba fruit extract improved spatial memory impairment induced by ethanol, due in part, by its antioxidant activities such as GSH level content. The possible antioxidant activities of extracts were due to the presence of tannins [1], carotenes [11] and flavonoids [25]. Additionally, Chen et al., [4] verified the bidirectional immune-modulatory roles of jujuba by regulating the expressions of pro-inflammatory cytokines in macrophages. Park et al., [24] suggested that Zizyphus jujuba Mill var. Spinosa prevents N-methyl-d-aspartate (NMDA)-induced neuronal cell damage in vitro. Studies also showed that it is used traditionally as tonic and aphrodisiac and sometimes as hypnotic-sedative and anxiolytic, anticancer, antifungal, antibacterial, antiulcer, antiinflammatory and wound healing properties $[12,20]$.

In a recent study performed by Chen et al., [4] ZJ extract was found to increase anti-oxidant enzyme levels in cultured astrocytes. In another study of the carbon tetrachloride-induced hepatitis by Kandimalla et al., [16] ZJ was reported to exert antioxidant activity in particular by increasing activities of catalase and superoxide dismutase enzymes and also reducing TBARS level, an important biomarker of lipid peroxidation, significantly.

\section{Conclusion}

Ziziphus jujuba is a widely traditionally used and potent medicinal plant amongst all the thousands of medicinal plants. It is an important source of compounds with theirs chemical structures as well as pharmacological properties. This study may be useful for predicting other medicinal uses and potential drug or food interactions and may be beneficial for people living where the jujuba fruits are prevalent and health care resources are scarce.

\section{References}

1. Adzu B, Amos S, Wambebe C, and Gamaniel K, (2001). Antinociceptive activity of Ziziphus spina christi root bark extract. Fitoterapia. 72, 344-350.

2. Cai YZ, Sun M, Corke H, (2003). Antioxidant activity of betalains from plants of the amaranthaceae. J Agric Food Chem. 51(8), 2288-2294.

3. Castellani RJ, Zhu X, Lee HG, Smith MA and Perry G, (2009). "Molecular pathogenesis of Alzheimer's disease: reductionist versus expansionist approaches, ” International Journal of Molecular Sciences. 10(3), 1386-1406.

4. Chen J, Maiwulanjiang M, Lam KY, Zhang WL, Zhan JY, Lam CT, Xu SL, Zhu KY, Yao P, Lau DT, Dong TT, Tsim $\mathrm{KW},(2014)$. A standardized extract of the fruit of Ziziphus jujuba (Jujuba) induces neuronal differentiation of cultured PC12 cells: a signaling mediated by proteinkinase. A. J Agric Food Chem. 62, 1890-1897.

5. Cheng G, Bai Y, Zzhao Y, Tao J, Liu Y, Tu G, Ma L, Liao N, $\mathrm{Xu}$ X, (2000). Flavonoids from Ziziphus jujuba Mill var. Spinosa. Tetrahadron, 56(45), 8915-8920.

6. Choi SH, Ahn JB, Kozukue N, Levin CE, Friedman M, (2011). Distribution of Free Amino Acids, Flavonoids, Total Phenolics, and Antioxidative Activities of Jujuba (Ziziphus jujuba) Fruits and Seeds Harvested from Plants Grown in Korea. J Agric Food Chem. 59(12), 6594-6604.

7. Emerit J, Edeas M, Bricaire F, (2004). Neurodegenerative diseases and oxidative stress. Biomed Pharmacother. 58, 39-46. 
8. Erel OA, (2005). New colorimetric method for measuring total oxidant status. Clin Biochem. 38(12):1103-11.

9. Floyd RA, Hensley K, (2002). Oxidative stress in brain aging. Implications for therapeutics of neurodegenerative diseases. Neurobiol Aging. 23(5), 795-807.

10. Gao QH, Wu PT, Liu JR, Parry JW, Wang M, (2011). Physico-chemical properties and antioxidant capacity of different jujuba (Ziziphus jujuba Mill.) cultivars grown in loess plateau of China. Scientia Horticulturae. 130(1), 6772.

11. Guil-Guerrero JL, Diaz Delgado A, Gonzalez MCM, and Torija Isasa ME, (2004). Fatty acids and carotenes in some ber (Ziziphus jujuba mill) varieties. Plant Foods Hum Nutr, 59, 23-27.

12. Gupta RB, Sharma S, Sharma JR, and Goyal R, (2004). Study on the physicochemical characters of fruits of some wild and cultivated forms/spp. (Zizpi hus spp.). Haryana Journal of Horticultural Sciences. 33(3/4), 167-169.

13. Hansen MB, Nielsen SE, Berg K, (1989). Re-examination and further development of a precise and rapid dye method for measuring cell growth/cell kill. Journal of Immunology Methods. 119, 203-210.

14. Huang YL, Yen GC, Sheu F, Chau CF, (2008). Effects of water-soluble carbohydrate concentrate from Chinese jujuba on different intestinal and fecal indices. J Agric Food Chem. 56, 1734-9.

15. Kaeidi A, Taati M, Hajializadeh Z, Jahandari F, Rashidipour M, (2015). Aqueous extract of Zizyphus jujuba fruit attenuates glucose induced neurotoxicity in an in vitro model of diabetic neuropathy. Iran J Basic Med Sci. 18, 301-306.

16. Kandimalla R, Dash S, Kalita S, Choudhury B, Malampati S, Kalita K, Kalita B, Devi R, Kotoky J, (2016). Protective Effect of Bioactivity Guided Fractions of Ziziphus jujuba Mill. Root Bark against Hepatic Injury and Chronic Inflammation via Inhibiting Inflammatory Markers and Oxidative Stress. Front. Pharmacol. 7, 298.

17. Kim MC, Cui FJ, Kim Y, (2013). Hydrogen Peroxide Promotes Epithelial to Mesenchymal Transition and Stemness in Human Malignant Mesothelioma Cells. Asian Pacific Journal of Cancer Prevention. 14(6), 3625-3630.

18. Kitamura Y, Ota T, Matsuoka Y, Tooyama I, Kimura H, Shimohama S, Nomura Y, Gebicke-Haerter PJ, Taniguchi T, (1999). Hydrogen peroxide-induced apoptosis mediated by 53 protein in glial cells. Glia. 25(2), 154-164.
19. Klaunig JE, Kamendulis LM, (2004). The role of oxidative stress in carcinogenesis. Annu Rev Pharmacol Toxicol. 44, 239-67.

20. Kumar S, Ganachari MS, Banappa, V, Nagoor S, (2004). Anti-inflammatory activity of Ziziphus jujuba Lam leaves extract in rats. Journal of Natural Remedies, 4(2), 183-185.

21. Mahajan RT, Chopda MZ, (2009). Phyto-Pharmacology of Ziziphus jujuba Mill-A plant review. Phog Rev. 3(6), 320329

22. Mark PM, (2004). Metal-catalyzed disruption of membrane protein and lipid signaling in the pathogenesis of neurodegenerative Disorders. Ann NY Acad Sci. 1012, 37-50.

23. Mitra A, and Dey B, (2013). "Therapeutic interventions in Alzheimer disease," in Neurodegenerative Diseases. InTech, Rijeka, chapter 12, 291-317.

24. Park JH, Lee HJ, Koh SB, Ban JY, (2004). Protection of NMDA-induced neuronal cell damage by methanol extract of Zizyphi Spinosi Semen in cultured rat cerebellar granule cells. Journal of Ethnopharmacology, 95 (1), 39-45.

25. Pawlowska AM, Camangi F, Bader A, and Braca A, (2009). Flavonoids of Zizyphus jujuba L. and Zizyphus spina-christi (L.) wild (Rhamnaceae) fruits. Food Chem. 112, 858-862.

26. Poon HF, Calabrese V, Scapagnini G, Butterfield DA, (2004). Free radicals: key to brain aging and heme oxygenase as a cellular response to oxidative stress. J Gerontol A Biol Sci Med Sci. 59(5), 478-93.

27. Salganik RI, (2001). The benefits and hazards of antioxidants: controlling apoptosis and other protective mechanisms in cancer patients and the human population. J Am Coll Nutr. 20, 464-72.

28. Taatil M, Alirezaei M, Meshkatalsadat MH, Rasoulian B, Moghadasi M, Sheikhzadeh F, Sokhtezari A, (2011). Protective effects of Ziziphus jujuba fruit extract against ethanol-induced hippocampal oxidative stress and spatial memory impairment in rats. Journal of Medicinal Plant Research. 5(6), 915-921.

29. Tavakkoli M, Miri R, Jassbi AR, Erfani N, Asadollahi M, Ghasemi M, Saso L, Firuzi O, (2014). Salvia and Stachys species protect neuronal cells against oxidative stress-induced apoptosis. Pharm Biol. 52(12), 1550-7.

30. Zheng W, Wang SY, (2001). Antioxidant activity and phenolic compounds in selected herbs. J Agric Food Chem. 49 (11), 5165-70. 